Kirol, C. P. and B. C. Fedy. 2021. Does habitat reclamation following energy development benefit songbird nest survival? Avian Conservation and Ecology 16(2):3. https://doi.org/10.5751/ACE-01913-160203

Copyright (C) 2021 by the author(s). Published here under license by the Resilience Alliance.

Research Paper

\title{
Does habitat reclamation following energy development benefit songbird nest survival?
}

\author{
Christopher P. Kirol ${ }^{1}$ and Bradley C. Fedy ${ }^{1}$ \\ ${ }^{1}$ School of Environment, Resources and Sustainability, University of Waterloo
}

\begin{abstract}
Songbird communities that rely on sagebrush habitat for breeding are experiencing steep population declines, while a large amount of the sagebrush ecosystem continues to be impacted by energy development. Reclamation is increasingly emphasized as a means of mitigating impacts on species that have been affected by oil and gas development; however, the response of sagebrush species to reclamation has largely been untested. We used nest survival of the Brewer's Sparrow (Spizella breweri breweri) as an indicator of fitness responses to short-term reclamation in sagebrush habitat. We assessed oil and gas reclamation $\sim 5$ years after reclamation, but sagebrush reestablishment is a slow process; thus, the legacy of these disturbances (i.e., disturbance scars) will likely remain for decades. We compared Brewer's Sparrow nest survival across a gradient of oil and gas development from undisturbed and active development to areas that had undergone oil and gas reclamation. Nest survival was assessed at multiple scales from microhabitat to landscape. The distribution of nest sites in the active and reclamation areas suggested local avoidance of disturbance, both active and reclamation disturbance, when establishing nesting territories. We found that reclamation benefited nest survival at a local-scale when disturbance exposure exceeded $15 \%$. Our findings demonstrated scale-dependent nest survival relationships. Across microhabitat and landscape scales, sagebrush canopy cover and composition were important to Brewer's Sparrow nest survival. Combined, these finding emphasize the importance of avoiding the removal of sagebrush habitat whenever possible and expediting sagebrush reestablishment in reclamation areas to maintain high quality sagebrush habitat for breeding songbird populations.
\end{abstract}

\section{La remise en état de l'habitat après installation d'aménagements énergétiques est-elle bénéfique pour la survie des nids de passereaux?}

RÉSUMÉ. Les communautés de passereaux qui dépendent des milieux d'armoises pour se reproduire connaissent une forte diminution de leurs populations, alors qu'une grande partie de l'écosystème à armoises continue d'être touchée par l'installation d'aménagements énergétiques. La remise en état est de plus en plus mise de l'avant comme moyen d'atténuer les impacts sur les espèces qui ont été affectées par l'installation de production pétrolière et gazière; cependant, la réponse des espèces nichant dans les milieux d'armoises à la remise en état n'a à peu près pas été testée. Nous avons utilisé la survie des nids du Bruant de Brewer (Spizella breweri breweri) comme indicateur du succès d'adaptation à la remise en état à court terme de milieux d'armoises. Nous avons évalué la restauration à des installations de production pétrolière et gazière environ 5 ans après la remise en état, mais le rétablissement de l'armoise est un processus lent; ainsi, les séquelles des perturbations (c'est-à-dire les « cicatrices » des perturbations) perdureront probablement pendant des décennies. Nous avons comparé la survie des nids de Bruant de Brewer sur un gradient d'installations de production pétrolière et gazière, allant de zones non perturbées et de construction active à des zones pétrolière et gazière ayant fait l'objet d'une remise en état. La survie des nids a été évaluée à plusieurs échelles, du microhabitat au paysage. La répartition des sites de nidification dans les zones actives et les zones remises en état indique que les oiseaux évitent localement les perturbations lors de l'établissement des territoires de nidification. Nous avons constaté que la remise en état favorisait la survie des nids à l'échelle locale lorsque l'exposition aux perturbations dépassait $15 \%$. Nos résultats ont montré que les relations de survie des nids dépendent de l'échelle. À l'échelle du microhabitat et du paysage, le couvert et la composition des milieux d'armoises étaient importants pour la survie des nids. Ensemble, ces résultats soulignent l'importance d'éviter, dans la mesure du possible, d'éliminer les milieux d'armoises et d'accélérer le rétablissement de l'armoise dans les zones de remise en état afin de maintenir un habitat d'armoises de haute qualité pour les populations de passereaux nicheurs.

Key Words: Brewer's Sparrow; energy development; indicator species; nest success; nest survival; oil and gas; reclamation; sagebrush songbirds

\section{INTRODUCTION}

Sagebrush ecosystems in North America provide habitat for approximately 350 plant and animal species, many of which are species of conservation concern (Knick et al. 2003, Davies et al. 2011). A large amount of the sagebrush ecosystem has been, or has the potential to be, impacted by energy development, primarily in the form of oil and gas (Copeland et al. 2011, Allred et al. 2015). Songbirds that rely on sagebrush habitat for breeding are one of the bird communities in North America experiencing the steepest population declines (Sauer et al. 2013, Rosenberg et al. 2016). Sagebrush specialist songbirds including the Brewer's Sparrow (Spizella breweri breweri) and Sage Thrasher 
(Oreoscoptes montanus) have declined by $35 \%$ and $44 \%$, respectively, since 1970 (Rosenberg et al. 2016). During the same timeframe, grassland specialist songbirds that often use sagebrush habitat for nesting such as the Vesper Sparrow (Pooecetes gramineus) and Lark Bunting (Calamospiza melanocorys) have also declined by $30 \%$ and $86 \%$, respectively (Rosenberg et al. 2016).

Energy development fields can be risky for songbirds because of direct mortalities and reduced fitness rates (Bayne and Dale 2011, Hethcoat and Chalfoun 2015a, Bernath-Plaisted and Koper 2016). Anthropogenic habitat modification can lead to maladaptive breeding strategies in birds in which behavioral cues become mismatched with survival and reproductive outcomes (Robertson and Hutto 2006). Nest productivity is a critical component of population persistence in birds (Saether and Bakke 2000) and increased predation is the primary mechanism that lowers nest survival in many habitats affected by anthropogenic development (DeGregorio et al. 2014, Hethcoat and Chalfoun 2015a, BernathPlaisted and Koper 2016). Anthropogenic habitat modification can result in heightened risk of nest predation due to changes in predator communities (e.g., expansion of novel predators that benefit from human subsidies), predator abundance, and predatorprey interactions (Winter et al. 2000, Chalfoun et al. 2002, Howe et al. 2014, Kirol et al. 2018). The specific mechanisms that drive impacts of energy development (i.e., increased predation risk) on songbird nest survival are not well understood (but see Sanders and Chalfoun 2019). Impacts of energy development on songbird nest survival have been attributed to the physical footprint (hereafter footprint) of development (native habitat removal, fragmentation, and anthropogenic edge; Hethcoat and Chalfoun 2015a, Bernath-Plaisted and Koper 2016, Sanders and Chalfoun 2018) and to specific energy infrastructure features such as power lines (DeGregorio et al. 2014).

Habitat fragmentation results in reduced habitat patch size, greater distance between patches, and increases in novel, often non-native, vegetation types (Andrén 1994). Edges are the transition zones between vegetation types and increase with habitat fragmentation (Murcia 1995). Research has demonstrated that changes in ecological conditions near edges can directly affect birds (Murcia 1995, Bayne and Dale 2011). Songbirds have been shown to avoid anthropogenic edge in many ecosystems when selecting nest sites (Bayne and Dale 2011, Ludlow et al. 2015, Thompson et al. 2015). Natural vegetation removal (i.e., direct habitat loss), habitat fragmentation, and anthropogenic edge can also depress nest survival by increasing exposure to nest predators (Winter et al. 2000, Vander Haegen 2007, Hethcoat and Chalfoun 2015b).

Infrastructure can negatively influence nest survival by giving nest predators a competitive advantage (DeGregorio et al. 2014, Howe et al. 2014, Bernath-Plaisted and Koper 2016). For instance, infrastructure (e.g., oil and gas structures and power lines) that can support the presence of perching predators and mid-sized mammalian predators (Liebezeit et al. 2009, DeGregorio et al. 2014, Howe et al. 2014). DeGregorio et al. (2014) found that Indigo Bunting (Passerina cyanea) nest survival was strongly and negatively influenced by distance to power lines. They also found that two primary nest predator species (American Crows [Corvus brachyrhynchos] and Brown-headed Cowbirds [Molothrus ater]) used power lines as perching structures and frequently preyed on songbird nests near the power lines.
It is important to consider multiple spatial scales when evaluating population fitness rates because landcover change and anthropogenic features may affect fitness rates through different mechanism at different spatial scales (Robinson et al. 1995, Chalfoun et al. 2002, Stephens et al. 2004, Llyod et al. 2005). At landscape scales, nest predation of forest-nesting songbirds increases as the forests become more fragmented (Robinson et al. 1995). At a local scale, Bernath-Plaisted and Koper (2016) found that grassland-nesting Vesper Sparrows had lower nest success when nest sites were within $1 \mathrm{~km}$ of oil and gas infrastructure and nest success rates continued to decrease as the proximity to infrastructure decreased.

Development of oil and gas reserves requires the clearing of vegetation for well pads and supporting infrastructure including access roads, facilities, and pipelines (sensu Walker et al. 2020). Oil and gas development is often considered a temporary disturbance because of the finite capacity of oil and gas production within areas and the mandated post-development reclamation that is generally required under conditions of approval by state and federal agencies (Andersen et al. 2009, Clement et al. 2014).

Reclamation of oil and gas disturbances is associated with specific regulations which involve the removal of infrastructure, recontouring (reshaping the disturbed area to the original contour of the surrounding landform), preparation of topsoil surface, and broadcasting of authorized seed mixes over the reclaimed areas (U.S. Bureau of Land Management 2003, Pyke et al. 2015, Rottler et al. 2018). Post-development reclamation is assumed to provide some immediate benefits to negatively effected wildlife by removing potential population stressors, such as above ground infrastructure and; therefore, is put forward as a mitigation measure for sagebrush associated species of conservation concern (U.S. Fish and Wildlife Service 2013, Clement et al. 2014). Much research has focused on the recovery of soil and vegetation following reclamation of disturbances in the sagebrush ecosystem (Avirmed et al. 2015, Davies et al. 2013, Gasch et al. 2016, Rottler et al. 2018). Yet, little research has looked at the response of sagebrush associated wildlife to reclamation following oil and gas disturbance (Barlow et al. 2020). To our knowledge no research has tested the effectiveness of reclamation as a mitigation measure for songbird communities.

The recovery of big sagebrush (Artemisia tridentata) is particularly challenging because it is a slow growing shrub (Baker 2011, Rottler et al. 2018). Wyoming big sagebrush (A. $t$. wyomingensis), the dominant sagebrush species in our study area, can take more than 80 years to return to pre-disturbance size and structure (Baker 2011, Gasch et al. 2016, Avirmed et al. 2015, Rottler et al. 2018). Consequently, the legacy of oil and gas disturbance in sagebrush stands and the associated habitat fragmentation will also persist for decades after the oil and gas infrastructure is removed.

Brewer's Sparrows are a short-lived sagebrush-obligate (i.e., dependent on sagebrush during critical life stages) songbird species that, under the right conditions, will attempt two and sometimes three nests per season (double and triple brood; Baker et al. 1976, Ehrlich et al. 1988, Rotenberry et al. 1999, Rowland et al. 2006). The sagebrush dependence during breeding and high potential reproductive output of the Brewer's Sparrow makes 
them an ideal indicator species to assess the potential mitigating effects of reclamation on bird populations breeding in sagebrush habitat (Niemi and McDonald 2004).

We assess early-stage reclamation in sagebrush landscapes approximately 5 years after oil and gas infrastructure was removed. Reclamation surfaces in our study had been revegetated with reclamation seed mixes but did not contained the sagebrush overstory component. Consequently, the vegetation structural characteristics of reclaimed surfaces in our study were similar to active oil and gas disturbances in that they both no longer contained the sagebrush overstory component. The primary difference between reclaimed surfaces and active disturbances was that the above ground infrastructure was removed and, instead of graveled roads or hard surface well pads, the reclaimed surface had seeded grass and forb ground cover. Therefore, comparing active oil and gas and reclamation soon after it took place provided a unique opportunity to better understand the mechanisms that affect songbird nest survival in oil and gas development areas. If, for example, infrastructure features or industrial noise are the primary drivers of increased nest predation in active oil and gas areas, we would expect nest survival rates to respond quickly and positively to reclamation. Conversely, if the primary causes of increased nest predation were driven more by vegetation loss, increased edge and fragmentation, we would expect that oil and gas reclamation would not immediately benefit nest survival because of the legacy of the disturbance due to the slow reestablishment of sagebrush vegetation communities.

We designed this study to address this question: how effective is early-stage reclamation at mitigating increased nest predation risk that act on sagebrush breeding songbirds during oil and gas development and production? We used nest survival of the Brewer's Sparrow as an indicator of potential fitness responses of sagebrush nesting birds to oil and gas reclamation. We explored this question across multiple spatial scales from landscape to microhabitat and by incorporating oil and gas development and sagebrush vegetation covariates in our nest survival models.

At the landscape scale, we hypothesized that nest survival would be the highest within undisturbed control sites and the lowest within active oil and gas sites and intermediate within reclamation sites because of the legacy of fragmentation and edge effects. At local scales, we hypothesized that nests proximate to oil and gas infrastructure and nests exposed to greater amounts of oil and gas disturbance would have the lowest nest survival and that edge and fragmentation effects would result in reduce nest survival of nests proximate to the reclamation footprint. Across scales, we hypothesized that sagebrush and other vegetation cover and density attributes surrounding nest sites would be predictive of nest survival and as cover and density of sagebrush and associated vegetation decreased nest survival would also decrease. Addressing these hypotheses will help us better understand the mechanisms that act to depress songbird nest survival in oil and gas development fields.

\section{METHODS}

\section{Study area}

Our study area was located in sagebrush-steppe habitat in northeastern Wyoming, USA, within the Powder River Basin
(PRB) region $\left(44.2603^{\circ} \mathrm{N},-106.3095 \mathrm{~W}^{\circ}\right.$; Fig. 1). Dominant shrubs included big sagebrush, black greasewood (Sarcobatus vermiculatus), rabbitbrush (Chrysothamnus and Ericameria spp.). Common grasses included native species such as blue grama (Bouteloua gracilis), bluebunch wheatgrass (Pseudoroegneria spicata), and invasive species such as Japanese brome (Bromus japonicas) and cheatgrass ( $B$. tectorum). In addition to the Brewer's Sparrow, other bird species we documented nesting in sagebrush stands in our study area included: Brewer's Blackbird (Euphagus cyanocephalus), Greater Sage-Grouse (Centrocercus urophasianus), Lark Bunting, Lark Sparrow (Chondestes grammacus), Loggerhead Shrike (Lanius ludovicianus), Mourning Dove (Zenaida macroura), Sage Thrasher, Spotted Towhee (Pipilo maculatus), Vesper Sparrow, and Western Meadowlark (Sturnella neglecta). Land use in the region was mainly oil and gas production and cattle ranching. Elevation ranged between 1268 $\mathrm{m}-1442 \mathrm{~m}$. Detailed descriptions of the region are available in previous publications (e.g., Doherty et al. 2010, Fedy et al. 2015).

Fig. 1. Map of study area and nest-searching plots for Brewer's Sparrow (Spizella breweri breweri) in northeastern Wyoming, USA, 2016-2018.

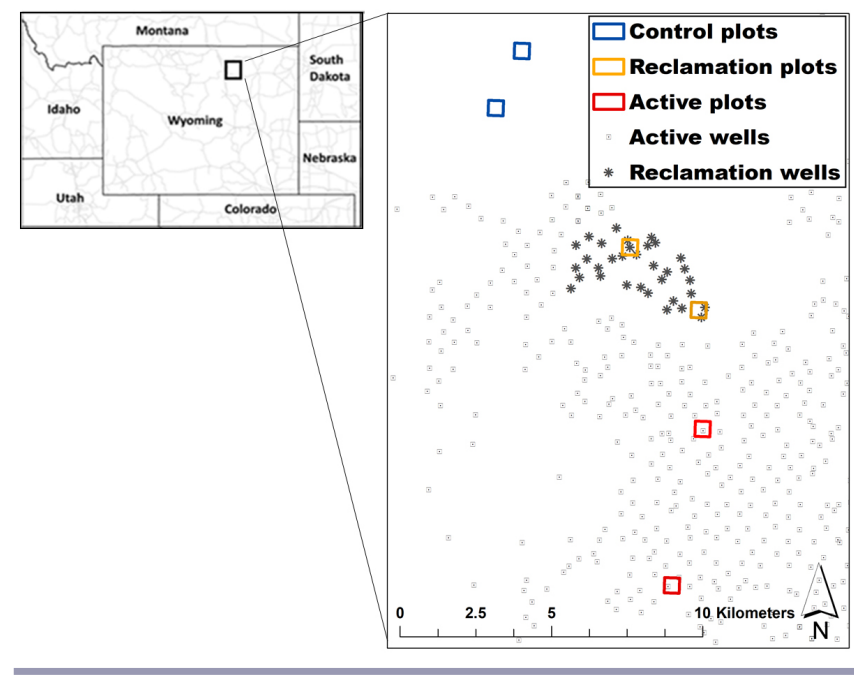

\section{Songbird indicator species}

Brewer's Sparrows begin arriving on their breeding grounds in late-April when males establish and defend breeding territories (Walker 2004, Harrison and Green 2010). Pairs are formed when the females arrive a few weeks later (Walker 2004, Harrison and Green 2010). Brewer's Sparrow pairs nest within their territories and maintain spacing between nests (Rotenberry et al. 1999). The size of Brewer's Sparrows breeding territories vary between regions, sites and years (Rotenberry et al. 1999). Reported territory sizes range between 0.25 - 2.0 hectares (Rotenberry et al. 1999, Walker 2004, Hansley and Beauvais 2004, Harrison et al. 2009). Brewer's Sparrows build a small open-cup nest $(\sim 8 \mathrm{~cm}$ diameter) with 3 to 6 eggs per clutch and will, generally, initiate two or three nests per season (Ehrlich et al. 1988, Rotenberry et al. 1999, Mahony et al. 2001). However, following nest failures, Brewer's Sparrows have been observed nesting more than three times per season (Chalfoun and Martin 2007). Egg-laying to 
fledging takes about 20-22 days (Rotenberry et al. 1999, Hansley and Beauvais 2004).

\section{Nest monitoring}

We searched for Brewer's Sparrow nests in six 500 x $500 \mathrm{~m}(0.25$ $\mathrm{km}^{2}$ ) plots distributed across the study area from 2016-2018 (Fig. 1). Nest searching took place between early May and mid-July each season. We used auditory and visual clues to locate nests and recorded the location of all active nests. Most nests were found during egg laying and incubation periods. We monitored nests every second day and increased monitoring to every day as fledging approached (Martin and Geupel 1993). We used nestling morphology to determine hatching date (Martin and Geupel 1993, Jongsomjit et al. 2007) and nest age, if we found the nest during the nestling period (Nur et al. 2004, Jongsomjit et al. 2007). Nests were considered depredated if eggs or young chicks were absent from the nest or if there were other signs of predation such as damaged nest, fledgling remains or egg fragments. If a nest was close to the estimated fledging date and we did not identify any sign of fledging (e.g., feces, fledglings in area) we considered the nest depredated (Martin and Geupel 1993). Successful nests produced at least one Brewer's Sparrow fledgling. We verified fledging by locating fledglings, observing adults carrying food or by listening for adult and fledgling communication calls close to the nest.

We calculated the nest initiation date (i.e., date the first egg was laid) on the basis of date of discovery of the nest and estimated age of the nest at discovery (Shaffer 2004). When the exact fate date (success or failed nest) was not known we assigned the nest fate date as the midpoint between the last monitoring intervals (Nur et al. 2004). Hatched nests, nests that survived the entire period, and nests with unknown fates, were right-censored (Hosmer and Lemeshow 2008). The exposure period ( $t$ ) for our nest survival analysis was $t=22$ days (egg laying $=3$ days, incubation $=10$ days, nestling stage $=9$ days; Petersen et al. 1986 , Rotenberry et al. 1999).

\section{Treatment and control plots}

Nest plots were selected across a gradient of energy development that included two "treatments" and a "control": 1) reclaimed oil and gas (treatment), 2) active oil and gas (treatment), and 3) nondeveloped habitat (control). Our study area contained coal-bed natural gas $(\mathrm{CBNG})$ wells that were developed at 3.1 well pads per $\mathrm{km}^{2}$ (32-ha spacing; Kirol et al. 2015b). On average, CBNG well pads required the clearing of 0.5 ha of natural vegetation. Two nest searching plots were positioned in each treatment and control area. All nest plots were in areas dominated by sagebrush landcover and were separated by $>2 \mathrm{~km}$ to ensure independence (Fig. 1).

\section{Reclamation and active disturbances}

In our study, active disturbances are surfaces that have been stripped of natural vegetation and are associated with producing CBNG wells (i.e., active wells), graveled access roads, and other supporting infrastructure (Fig. 2). Reclamation or reclaimed surfaces were previously active CBNG disturbances (e.g., wells and access roads) that had been reclaimed (Fig. 2). Specifically, reclaimed surfaces had undergone reclamation that included the removal of all above ground infrastructure such as well structures and power lines (U.S. Bureau of Land Management 2003). Reclamation requirements included stripping and re-spreading topsoil, and re-contouring well pads, access roads and other infrastructure disturbances (U.S. Bureau of Land Management 2003). Once the reclamation surfaces were prepared, seeding was completed with a no-till drill (U.S. Bureau of Land Management 2003). Documentation of seed mixes used in this area were unavailable but authorized seed mixes generally contained a mix of forb, grass and shrub species (Gasch et al. 2016, Rottler et al. 2018). Sagebrush reestablishment was expected to occur naturally from surrounding areas (U.S. Bureau of Land Management 2003). The reclamation site in our study contained $30 \mathrm{CBNG}$ wells that were plugged and reclaimed in 2013 (Figs. A1.1. and A1.2). The area influenced directly by reclamation of these $30 \mathrm{CBNG}$ wells was $\sim 8.6 \mathrm{~km}^{2}$.

Fig. 2. The footprint of disturbance quantified using heads-up digitizing and converted to a $1-\mathrm{m}$ raster for analysis. Selected Brewer's Sparrow (Spizella breweri breweri) nests (blue dots) and $50 \mathrm{~m}$ radius scale (blue circles), northeastern Wyoming, USA. Panel A shows the area digitized as active disturbance and panel B shows area digitized as reclamation with imagery in the background. The disturbance polygons encompass all of the area disturbed (e.g., sagebrush removed) for the well pads and access roads (panels a, b). Some of the disturbed habitat around active development (A) has filled in with grass and forb cover. The reclaimed surface is dominated by grass and forb cover but lacks the sagebrush overstory (B). Nests are exposed to $25 \%$ active disturbance (panels $\mathrm{A}$, a) and $23 \%$ reclamation (Panels B, b) within 50m.
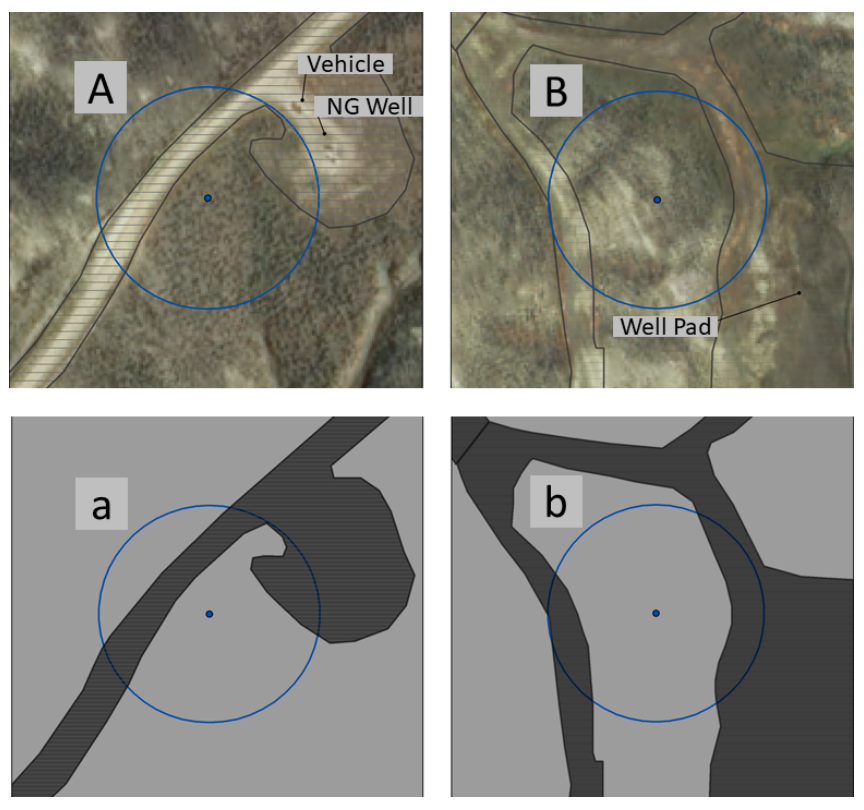

\section{Nest plot selection}

We selected control, active and reclamation nest plots that had similar vegetation communities and topographic characteristics to minimize influences of natural variation and maximize the isolation of the treatment effects of interest (i.e., active oil and 
Table 1. Covariates assessed in Brewer's Sparrow (Spizella breweri breweri) nest survival models representing multiple scales from the individual nest shrub to a $100 \mathrm{~m}$ radius around a nest, Wyoming, USA.

\begin{tabular}{|c|c|c|}
\hline Covariate & Scale & Description \\
\hline \multicolumn{3}{|l|}{ Microhabitat } \\
\hline ShrubHeight & Nest shrub & Height of shrub, excluding inflorescences $(\mathrm{cm})$ \\
\hline NestHeight & Nest shrub & Height to the bottom of nest cup from ground $(\mathrm{cm})$ \\
\hline Vigor & Nest shrub & $\%$ of alive foliage (nearest $10 \%$ ) \\
\hline Grass & $5 \mathrm{~m}$ radius & $\%$ grass cover, excluding invasive grass \\
\hline InvasiveGrass & $5 \mathrm{~m}$ radius & $\%$ invasive grass cover (Bromus tectorum and B. japonicas) \\
\hline Forbs & $5 \mathrm{~m}$ radius & $\%$ forb cover \\
\hline BareSoil & $5 \mathrm{~m}$ radius & $\%$ bare ground cover \\
\hline GrassHeight & $5 \mathrm{~m}$ radius & Average grass droop height $(\mathrm{cm})$, excluding invasive grass \\
\hline VisualObst & $5 \mathrm{~m}$ radius & Visual obstruction (horizontal cover; $\mathrm{dm}$ ) \\
\hline PercARTRL & $5 \mathrm{~m}$ radius & $\%$ live big sagebrush (Artemisia tridentata) canopy cover \\
\hline DenseARTRL & $5 \mathrm{~m}$ radius & Average live big sagebrush density (plants $/ \mathrm{m}^{2}$ ) \\
\hline HeightMean & $5 \mathrm{~m}$ radius & Average big sagebrush height $(\mathrm{cm})$ \\
\hline HeigthSD & $5 \mathrm{~m}$ radius & Variability (standard deviation $[\mathrm{SD}]$ ) in sagebrush height \\
\hline \multicolumn{3}{|l|}{ Spatial } \\
\hline NDVI & $30,50,100(\mathrm{~m})$ radii & $\begin{array}{l}\text { Mean NDVI (Normalized Difference Vegetation Index) value per scale ( } 30-\mathrm{m} \text { resolution; } \\
\text { Robinson et al. 2017) }\end{array}$ \\
\hline ForbGrs & $30,50,100(\mathrm{~m})$ radii & Mean forb and grass understory cover per scale (30-m resolution; Jones et al. 2018) \\
\hline BigSage & $30,50,100(\mathrm{~m})$ radii & $\%$ big sagebrush cover per scale (30-m resolution; Xian et al. 2015) \\
\hline SageHgt & $30,50,100(\mathrm{~m})$ radii & Average big sagebrush height per scale (30-m resolution; Xian et al. 2015) \\
\hline SDSageHgt & $50,100(\mathrm{~m})$ radii & Variability (SD) in sagebrush height per scale (30-m resolution; Xian et al. 2015) \\
\hline \multicolumn{3}{|l|}{ Anthropogenic } \\
\hline ActiveDist & $30,50,100(\mathrm{~m})$ radii & $\%$ active disturbance footprint per scale (1-m resolution) \\
\hline RDist & $30,50,100(\mathrm{~m})$ radii & $\%$ reclaimed footprint per scale ( $1-\mathrm{m}$ resolution) \\
\hline PwrLine & $30,50,100(\mathrm{~m})$ radii & Distance to nearest overhead power line as a decay per scale \\
\hline \multicolumn{3}{|l|}{ Temporal } \\
\hline Year & NA & Study year \\
\hline JulianDay & NA & Julian date of start of nest incubation \\
\hline
\end{tabular}

gas and reclaimed oil and gas disturbances). Because the reclamation site was the most spatially limited treatment, we first selected plots within this treatment and used the habitat characteristics of the reclamation treatment plots to guide the selection of the active treatment and control plots. Using geographic information systems (GIS), we first selected reclamation plots based on four primary criteria: 1) sagebrush was the dominant landcover, 2) contained at least one reclaimed CBNG well, 3) $\geq 600 \mathrm{~m}$ from an active natural gas wells, $\geq 300 \mathrm{~m}$ from gravel access roads and overhead power lines, and 4) located predominantly on public land (Wyoming State or BLM). These influence distances for wells, roads and power lines were informed by previous research on the response of songbirds to development (Ingelfinger and Anderson 2004, Bayne and Dale 2011, Yoo 2014, Thompson et al. 2015).

We then used spatial layers representing elevation, and vegetation cover in GIS to match active and control treatment plots to the range of vegetation and topographic characteristics of the reclamation plots. Based on the values derived from the reclamation plots, the active treatment and control plots we selected had average sagebrush cover of $10-14 \%$, terrain roughness values between 50-550, and an average elevation between 1,200-1,400 m. Additionally, the active treatment plots contained $\geq 1$ well(s) to provide a direct comparison to the reclamation plots that contained $\geq 1$ well(s) that had been reclaimed. This GIS assessment provided a candidate set of control and active plots that were randomly numbered. We then sequentially examined plots and selected the first plots that we confirmed met all of these criteria and that were accessible for field work. Sagebrush spatial layers for site selection were processed from Wyoming sagebrush products (Homer et al. 2012). Roughness values were based upon a terrain roughness index (Evans et al. 2014) derived from a Digital Elevation Map (DEM). Average elevations within plots were also calculated from a DEM (Evans et al. 2014). All plots were separated from each other by $>1 \mathrm{~km}$.

\section{Microhabitat covariates}

Microhabitat characteristics of a nest site can influence nest survival of sagebrush associated birds (Coates and Delehanty 2010, Ruehmann et al. 2011). We measured and compiled a suite of biologically-relevant microhabitat covariates at nest locations (Table 1). We sampled microhabitat characteristics of the nest shrub and a $5 \mathrm{~m}$ radius around the nest shrub (i.e., nest patch). The nest shrub formed the center of two perpendicular $10 \mathrm{~m}$ transects. We measured nest-shrub characteristics including shrub height, height of nest within the shrub and shrub vigor. We measured nest-patch characteristics including grass ground cover, invasive grass ground cover, forb ground cover, bare soil ground cover, average grass height, sagebrush canopy cover, sagebrush plant density, average sagebrush height, variability in sagebrush height and visual obstruction (Table 1). Barlow et al. (2019) 
provides a detailed description of our microhabitat sampling methods. To minimize detrimental effects on nest initiation and egg and chick survival, we sampled Brewer's Sparrow nest sites after the Brewer's Sparrow nesting season concluded each year.

\section{Spatial covariates}

In addition to our microhabitat data collected in the field, we also quantified habitat structure by summarizing GIS data across three larger spatial scales because songbird nest survival can be influenced at multiple spatial scales (Stephens et al. 2004). The spatial scales we assessed were informed by previous research on Brewer's Sparrows (Rotenberry et al. 1999, Carlisle et al. 2018). The radii of these three scales were $30 \mathrm{~m}, 50 \mathrm{~m}$ and $100 \mathrm{~m}$. Within these scales we used zonal statistics to calculate vegetation covariates including mean Normalized Difference Vegetation Index (NDVI), mean forb and grass understory cover, percent big sagebrush canopy cover, average sagebrush height $(\mathrm{cm})$, and the standard deviation of sagebrush height (Table 1; Xian et al. 2015, Robinson et al. 2017, Jones et al. 2018, Yang et al. 2018). NDVI is as a measure of primary productivity (Robinson et al. 2017). The standard deviation in sagebrush height represented sagebrush height variability surrounding a nest. Higher standard deviation values were associated with greater horizontal heterogeneity and lower values with lower horizontal heterogeneity (sensu Williams et al. 2011).

Greater grass and forb cover and higher NDVI values can be positively associated with the abundance of deer mice (Peromyscus maniculatus), which are known to depredate Brewer's Sparrow nests (Hanser et al. 2011, Heathcoat and Chalfoun 2015a, Sanders and Chalfoun 2018). We used 30-m resolution NDVI products generated every 16 days (Robinson et al. 2017) to calculate Mean NDVI layers. We obtained four NDVI composites from approximately May $9^{\text {th }}$ to June $26^{\text {th }}$ to overlap the Brewer's Sparrow nesting period each year (2016 - 2018). We then averaged these four composites to generate NDVI values to match with those year's nests. We used available 30-m resolution annual forb and grass and perennial forb and grass percent cover layers for each year of the study (Jones et al. 2018). We summed the annual and perennial forb and grass layers to generate a forb and grass percent cover value per scale (Table 1).

Vegetation structure (e.g., horizontal and vertical cover) and composition can influence nest survival of ground or shrub nesting birds (Maresh Nelson et al. 2018). We used 2016 shrubland layers (30-m resolution) available through the U.S. National Land Cover Database (NLCD) to calculate vegetation concealment covariates including percent big sagebrush canopy cover, average sagebrush height $(\mathrm{cm})$ and the standard deviation of sagebrush height per scale (Xian et al. 2015, Yang et al. 2018). We did not calculate standard deviation in sagebrush height at the $30 \mathrm{~m}$ scale because this scale was equivalent to the resolution of the data set (30-m resolution; Table 1).

Anthropogenic structures and modification of nesting habitat can increase nest predation risk in songbirds (Vander Hagen 2007, Heathcoat and Chalfoun 2015a, Bernath-Plaisted and Koper 2016). We quantified disturbances at each scale that were associated with active oil and gas (e.g., well pads) or reclamation (e.g., reclaimed well pads). We used National Agriculture Imagery Program (NAIP) imagery to heads-up digitize the footprint of disturbance at a 1:1000 map scale and converted these disturbance polygons to a 1-m resolution raster layer (http://datagateway.nrcs. usda.gov). We quantified the footprint of active disturbance and reclamation as the percent of surface disturbance per scale (Fig. 2). All GIS data was processed using ArcGIS Desktop 10.7 (http:// www.esri.com) and QGIS 3.10 (qgis.osgeo.org).

Overhead power lines are a type of supporting infrastructure that is generally not associated with a physical footprint or removal of habitat. In oil and gas development areas, including our study area, power lines often span undisturbed sagebrush habitat with minimal surface disturbance (i.e., a power pole approximately every $100 \mathrm{~m}$ ). Proximity to power lines can negatively influence songbird nest survival because some avian nest predators use power lines and poles as perching structures (DeGregorio et al. 2014). We quantified distance from nests to power line using exponential distance decay functions to account for decreasing magnitude of influence with an increasing distance from the power line on nest survival (Fedy and Martin 2011). Decay values were calculated using the form $e^{(-d / \alpha)}$ where $d$ was the distance in meters (from nest to power line) and $\alpha$ was set to correspond to each radii $-30 \mathrm{~m}, 50 \mathrm{~m}$ and $100 \mathrm{~m}$ (Table 1; Kirol et al. 2015b).

\section{Modeling approach}

To assess relationships between covariates and Brewer's Sparrow nest survival we used a mixed-effects Cox proportional hazards model (function: coxme) in $\mathrm{R}$ ( $\mathrm{R}$ version 3.6.0; Therneau 2020). We modeled environmental covariates that potentially influenced Brewer's Sparrow nest survival from four categories that included temporal, microhabitat, spatial and anthropogenic disturbance. Temporal covariates included year and Julian date. We modeled year to account for potential variability in nest survival between years and Julian date because nest survival may be related to when the nest was initiated (Dinsmore et al. 2002). We selected models in three steps using sample-size-adjusted Akaike's Information Criteria $\left(\mathrm{AIC}_{c}\right)$ to compare and rank models within each step (Burnham and Anderson 2002) as described below. We standardized all covariates prior to modeling. We considered both linear and quadratic terms for the footprint of disturbance covariates because avian fitness metrics can have nonlinear relationships with exposure to increasing amounts of surface disturbance (Kirol et al. 2015a). We tested for potential correlation between covariates using Pearson's correlation matrix; we did not include any two co-varying variables $(|r| \geq 0.6)$ in any model. When covariates were correlated, we selected the covariate with the lowest $\mathrm{AIC}_{c}$ in a single covariate model comparison. The single covariate model also contained the random effects plot and treatment described below. At each stage, the best-fit AIC model, that only contained informative parameters (Arnold 2010), was brought forward to the next model selection step. We disregarded models differing from the best-fit model by one parameter and within $2 \Delta \mathrm{AIC}_{c}$ if the slope coefficient was uninformative with $85 \%$ confidence limits overlapping zero (Burnham and Anderson 2002, Arnold 2010).

To account for the spatial clustering of our nest data and allow us to share information across the sample of nests (Bolker et al. 2009, Kéry and Royle. 2016), our first step involved developing a model with plot identification and treatment type as categorical covariates (Fig. 1). Plot was included as a random effect within treatment (nested structure) because our data were obtained from different nest plots $(n=6)$ within treatment areas $(n=3)$. This random-effect model structure was included in all subsequent 
Table 2. Final Cox proportional hazard model describing relationships between temporal, microhabitat, spatial and anthropogenic covariates and Brewer's Sparrow nest survival. The base-model accounted for environmental variation in Brewer's Sparrow nest survival to allow for interpretation of the influence of anthropogenic disturbance covariates on Brewer's Sparrow nest survival, Wyoming, USA.

\begin{tabular}{|c|c|c|c|c|}
\hline \multirow[b]{2}{*}{ Covariate (scale) } & \multirow[b]{2}{*}{ Coefficient } & \multirow[b]{2}{*}{ Risk ratio } & \multicolumn{2}{|c|}{ Risk ratio $85 \% \mathrm{CI}$} \\
\hline & & & Lower & Upper \\
\hline \multicolumn{5}{|c|}{ Base-model with plot nested in treatment as a random effect } \\
\hline JulianDay & 0.224 & 1.251 & 1.015 & 1.543 \\
\hline NestHeight (nest shrub) & 0.170 & 1.185 & 0.972 & 1.445 \\
\hline DenseARTRL ( $5 \mathrm{~m}$ radius) & -0.248 & 0.781 & 0.626 & 0.973 \\
\hline BigSage (100m radius) & -0.156 & 0.856 & 0.673 & 1.088 \\
\hline \multicolumn{5}{|c|}{ Base-model $+\%$ active disturbance } \\
\hline ActiveDist + & -0.523 & 0.592 & 0.346 & 1.013 \\
\hline ActiveDist $^{2}$ (50m radius) & 0.642 & 1.901 & 1.127 & 3.210 \\
\hline
\end{tabular}

modeling steps. For spatial covariates measured at multiple spatial scales, we first optimized the scale by comparing single covariate models, in combination with our random effects, and brought forward the covariate scale with the lowest $\mathrm{AIC}_{c}$ to the next modeling step.

In the second modeling step, we modeled the temporal covariates Julian date and year with our random effects to determine if these covariates improved model fit (Table 1). This model moved forward to the third modeling step, in which we considered microhabitat and spatial covariates. The best-fit model from this step, with the lowest $\mathrm{AIC}_{c}$ and only containing informative parameters, formed our base-model (Webb et al. 2012, Kirol et al. 2015b). The purpose of the base-model was to account for environmental variation in Brewer's Sparrow nest survival (i.e., as statistical control covariates; Hosmer and Lemeshow 2008) to facilitate interpretation of the anthropogenic covariates.

In our final modeling step, we tested decay distance to power lines and different functional relationships (linear and quadratic) of our surface disturbance covariates, at each scale, with our basemodel. We assessed support for decay distance to power lines and different functional forms (i.e., linear or quadratic) of the disturbance covariates based on $\mathrm{AIC}_{c}$ and the coverage of the $85 \%$ confidence intervals. If an anthropogenic covariate was influencing Brewer's Sparrow nest survival, we expected the anthropogenic covariate would be informative, have $85 \%$ confidence interval coverage that did not overlap 0 , when combined with the base-model (Arnold 2010, Bernath-Plaisted and Koper 2016).

We reported $85 \%$ confidence intervals for parameters to be consistent with the $\mathrm{AIC}_{c}$ model selection process (Arnold 2010). For interpretation of the effect of a unit change in individual covariates on Brewer's Sparrow nest survival, we modeled the nonstandardized form of the supported covariates. To ensure that the proportional hazards assumption was not violated, we plotted Schoenfeld residuals for our final model as well as each individual covariate in our final model (Hosmer and Lemeshow 2008). For the purpose of reporting nest survival estimates for each treatment type and year we modeled them as fixed effects in univariate models (function: coxph; Therneau 2019).

\section{RESULTS}

Our survival analysis included 107 Brewer's Sparrow nests monitored between 2016-2018 $(n=31$ in 2016, $n=41$ in 2017 and $n=35$ in 2018). Across years we monitored 22 nests in the control, 41 in the reclamation treatment and 44 in the active treatment. Nest predation was the cause of nest failure in all of the nests included in our analysis. We did not find a single nest that was located within the active disturbance or reclamation footprint. Model adjusted nest survival estimates for a 22 day Brewer's Sparrow nest survival period for the entire sample were $54 \%(85 \%$ CI: 48-62\%). Model adjusted Brewer's Sparrow nest survival did not differ significantly $(p \geq 0.714)$ between years $(2016=56 \%[85 \%$ CI: 45-71\%], $2017=53 \%$ [85\% CI: 43-65\%], $2018=54 \%$ [85\% CI: $44-67 \%])$ or differ significantly $(p \geq 0.257)$ between active treatment $(61 \%$ [85\% CI: $51-72 \%])$, reclamation treatment $(51 \%$ [85\% CI: 41-63\%]), and control (47\% [85\% CI: 34-65\%]).

\section{Base-model}

Our best-fit model that formed our base-model contained temporal, microhabitat and spatial covariates: JulianDay, NestHeight (nest shrub), DenseARTRL (5m radius), and BigSage (100m radius; Fig. 3 ). The predictive microhabitat covariates were live big sagebrush plant density (DenseARTRL; plants $/ \mathrm{m}^{2}$ ) and the height from the ground to the bottom of the nest cup (NestHeight). BigSage represents the percent of big sagebrush cover surrounding a nest. JulianDay, DenseARTRL, NestHeight and BigSage had $85 \%$ CIs that slightly overlapped 0 when combined with the other covariates in the best-fit model. We decided to retain these because they were present in the majority of the $2 \Delta \mathrm{AIC}_{c}$ model set and did not have overlapping $85 \% \mathrm{CIs}$ unless all 4 of these covariates were in the same model (Table 2). BigSage and DenseARTRL were both positively associated with Brewer's Sparrow nest survival (Fig. 3). Our base-model predicted that as the amount of big sagebrush cover within $100 \mathrm{~m}$ of a nest and the density of live big sagebrush shrubs within $5 \mathrm{~m}$ of a nest positively influence nest survival. Julian date (JulianDay) suggests that nests initiated later in the season are at greater risk of failure (Fig. 3). Nest height suggests that nests built higher in the nest shrub experience higher risk than those built lower in the nest shrub (Table 2). When compared to the null model, the basemodel (i.e., covariate adjusted model) explained much of the variability in nest survival between the active treatment (59\% [85\% 
CI: 49-71\%]) and reclamation treatment (56\% [85\% CI: 46-69\%]), but little variability between the two treatments and control $(45 \%$ [85\% CI: 32-64\%]).

Fig. 3. Standardized risk ratios and associated $85 \%$ confidence intervals for all covariates that were predictive of Brewer's Sparrow (Spizella breweri breweri) Standardized risk ratios and associated $85 \%$ confidence intervals for all covariates that were predictive of Brewer's Sparrow nest survival in northeastern Wyoming, USA, 2016-2018. JulianDay is a temporal covariate, NestHeight and DenseARTRL (5m) are microhabitat covariates measured in the field, BigSage $(100 \mathrm{~m})$ and ActiveDist (50m) are spatial covariates derived in Geographic Information Systems (GIS). nest survival in northeastern Wyoming, USA, 2016-2018. JulianDay is a temporal covariate, NestHeight and DenseARTRL $(5 \mathrm{~m})$ are microhabitat covariates measured in the field, BigSage $(100 \mathrm{~m})$ and ActiveDist $(50 \mathrm{~m})$ are spatial covariates derived in Geographic Information Systems (GIS).

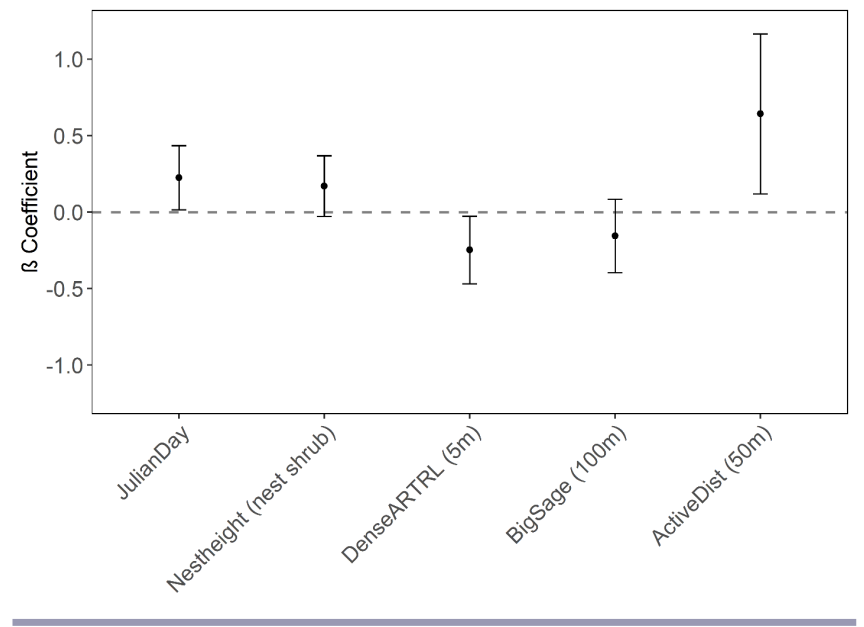

\section{Anthropogenic covariates}

When combined with our base-model, decay distance to power lines (PwrLine) was not supported as having a relationship with nest survival at any of the scales assessed. We did not find support for a linear relationship between the amount of active disturbance (ActiveDist) and nest survival at any scale. At the $50 \mathrm{~m}$ scale, the quadratic form of active disturbance (ActiveDist + ActiveDist ${ }^{2}$ ) had the most support as having a relationship to Brewer's Sparrow nest survival (Fig. 4 and Table 2). The $85 \%$ CIs of the squared term did not overlap 0 . But the linear term had $85 \%$ CIs that slightly overlapped 0 (Table 2). The quadratic form suggests that exposure of Brewer's Sparrow nests to active disturbance within $50 \mathrm{~m}$ initially did not influence nest risk until disturbance reached $\sim 15 \%$. Nest survival risk increased steeply when disturbance reached $\sim 30 \%$ (Fig. 4). At the $50 \mathrm{~m}$ scale, $20 \%$ of our nest sample in the active treatment were exposed to $\geq 15 \%$ disturbance. The low sample size at the high end of the distribution $(\geq 15 \%)$ increased uncertainty as demonstrated by the widening CIs (Fig. 4). Our nest survival model predicted that the probability of a nest being successful was approximately $16 \%$ higher for nests not exposed to active disturbance compared to nests exposed to $30 \%$ active disturbance within $50 \mathrm{~m}$.
Fig. 4. Brewer's Sparrow (Spizella breweri breweri) nest survival risk at a $50 \mathrm{~m}$ radius scale, northeastern Wyoming, USA. Solid lines represent coefficient estimates and dashed lines represent $85 \%$ confidence intervals. Graph A shows nest survival risk relative to the percent active disturbance exposure. Graph B shows nest survival risk relative to the percent reclamation exposure.

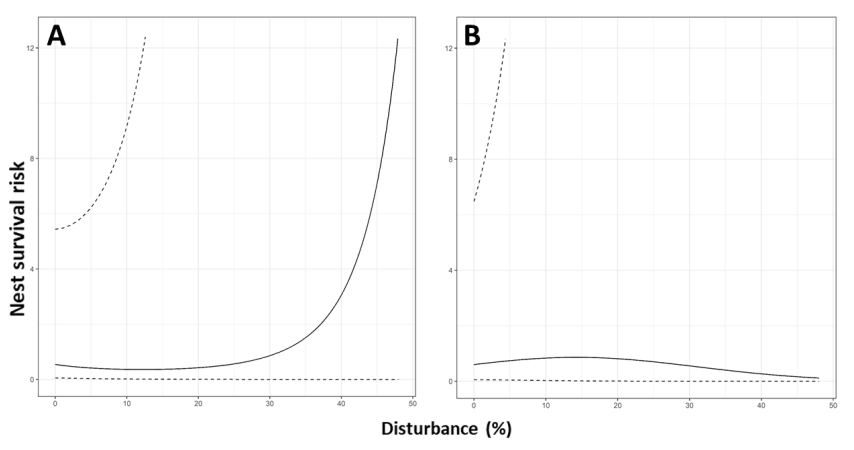

Sixty-six percent of the active treatment nests were exposed to $0 \%$ disturbance at the $30 \mathrm{~m}$ scale. At the $50 \mathrm{~m}$ and $100 \mathrm{~m}$ scales, $48 \%$ and $25 \%$ of the nests were exposed to $0 \%$ disturbance. The mean distance $( \pm \mathrm{SE})$ from nests to the nearest active disturbance was $62.87 \pm 7.12 \mathrm{~m}($ range $=3.16-181.73 \mathrm{~m})$.

Across the two active nest-searching plots an average of 7.59 $\pm 0.80 \%$ (range $=6.79-8.40 \%$ ) of the plot contained active disturbance. This amount of disturbance introduced an average of $2.38 \pm 0.34 \mathrm{~km}$ (range $=2.04-2.72 \mathrm{~km})$ of edge.

We did not find support for a linear or quadratic relationship between reclamation (ReclDist) and nest survival at the $50 \mathrm{~m}$ scale or the other scales $(30 \mathrm{~m}$ and $100 \mathrm{~m}$ radii) assessed. Exposure to reclamation is similar to that of active disturbance with $17 \%$ of the sample of nests in the reclamation treatment being exposed to $\geq 15 \%$ disturbance. To further examine potential differences in Brewer's Sparrow nest survival when exposed to reclamation instead of active disturbance, we modeled the quadratic term at the same scale ( $50 \mathrm{~m}$ radius) as the supported active disturbance relationship and found that in addition to the lack of statistical support the coefficient slope is relatively flat (Fig. 4).

Of the reclamation treatment nests, $78 \%$ were exposed to $0 \%$ reclamation at the $30 \mathrm{~m}$ scale, $46 \%$ were exposed to $0 \%$ reclamation at the $50 \mathrm{~m}$ scale, and $23 \%$ were exposed to $0 \%$ reclamation at the $100 \mathrm{~m}$ scale. The mean distance from nests to the nearest reclamation surface was nearly equivalent to the active treatment nests $(61.41 \pm 6.47 \mathrm{~m}$ [range $=3.00-161.28 \mathrm{~m}])$.

Across the two reclamation nest-searching plots an average of $9.47 \pm 2.31 \%$ (range $=7.17-11.78 \%$ ) of the plot contained reclamation. The reclamation footprint introduced an average of $2.26 \pm 0.27 \mathrm{~km}$ (range $=1.98-2.53)$ of edge.

Our final model explaining Brewer's Sparrow nest survival included multiple scales from the individual nest shrub to the amount of big sagebrush cover in a 3.14 hectare ( $100 \mathrm{~m}$ radius) area around a nest. 


\section{DISCUSSION}

Habitat quality is a function of an occupied habitat's conduciveness to survival and reproduction (Hall et al. 1997). Therefore, the effectiveness of reclamation as a mitigation measure should be gauged not only by occurrence of an animal in a reclaimed habitat but also by fitness outcomes. We found that survival of Brewer's Sparrow nests was influenced by factors at multiple spatial scales reiterating the importance of looking at multiple scales when assessing fitness outcomes (Stephens et al. 2004, Ibáñez-Álamo et al. 2015). We did not find an overall difference in nest survival between reclamation and active treatments and the control. However, at a local scale, our findings suggest that reclamation positively influenced Brewer's Sparrow nest survival when compared to active oil and gas disturbance. Covariates representing sagebrush density and canopy cover were positively related to Brewer's Sparrow nest survival at more than one scale, emphasizing the reproductive benefits of unfragmented sagebrush stands to Brewer's Sparrow populations and the importance of reestablishing sagebrush on reclamation surfaces.

We found two microhabitat characteristic, the density of live sagebrush surrounding the nest and the height of the nest bowl in the nest shrub, that were related to Brewer's Sparrow nest survival. Nest sites within denser patches of sagebrush have greater concealment that may reduce the risk of being discovered by ground predators. Therefore, this finding may simply be explained by greater vertical concealment leading to lower predation risk (Martin 1993, Williams et al. 2011). At a similar microhabitat scale, Chalfoun and Martin (2007) found that as the density of potential nest shrubs (sagebrush shrubs of similar height and crown width as shrubs used for nesting) increased Brewer's Sparrow nest predation risk decreased. Although we did not directly measure the density of potential nest shrubs, as did Chalfoun and Martin (2007), higher shrub densities in our study may be correlated with higher densities of potential nest shrubs resulting in decreased predator efficiency at locating nests (potential-prey-site hypothesis; Martin 1993).

Our results suggest that nests constructed higher in the nest shrub were at greater risk of predation. Brewer's Sparrow nests higher in the nest shrub likely had less overhead concealment which may increase the likelihood of being discovered by avian predators. Unfortunately, few studies of shrub-nesting songbirds have quantitatively assessed the impact of nest height on the probability of survival (but see Latif et al. 2012). Avian predators known to depredate Brewer's Sparrow nests were present in our study area including Black-billed Magpies (Pica hudsonia) and Loggerhead Shrikes (Lanius ludovicianus; Vander Haegen et al. 2002, Hethcoat and Chalfoun 2015b, Barlow et al. 2020).

At a larger scale (100m radius), Brewer's Sparrow nests were more successful in areas with higher mean sagebrush canopy cover which represented more contiguous sagebrush stands. Chalfoun and Martin (2007) found increased number of nesting attempts per Brewer's Sparrow pair with increased shrub cover (primarily sagebrush shrubs) within approximately $300 \mathrm{~m}$ of the nest. Nest survival of a larger, ground-nesting bird, the Greater Sage-Grouse (Centrocercus urophasianus), also benefits from greater sagebrush cover surrounding nest sites. Sage-grouse nests in our study area were more likely to be successful if the surrounding habitat $(\sim 340 \mathrm{~m}$ radius) had more sagebrush canopy cover (Kirol et al. 2015b). The reduced predation risk of Brewer's Sparrow nests in areas with greater amounts of sagebrush highlights the importance of sagebrush reestablishment in reclamation areas. Yet, the long-term prospects of sagebrush recovery in disturbed habitats are uncertain. For instance, natural sagebrush reestablishment (i.e., without planting), on reclamation surfaces in our study area will likely take from 25 to 125 years (Davies et al. 2013, Avirmed et al. 2015, Rottler et al. 2018). Thus, our findings suggest that some level of impact of oil and gas development on Brewer's Sparrow nest survival will also likely persist for until the disturbance scars have filled in with sagebrush.

At the broadest spatial scale we assessed (i.e., nest-searching plots within different treatments), we found no evidence of differences in nest survival between active and reclaimed treatments and those in our control. One possibility is that the unexpected similarity across sites could have been influenced by reduced human activity associated with the active oil and gas sites in our study (Barlow et al. 2020). Predator-prey dynamics are complex and contextspecific. The relationships among energy-related habitat modification and nest survival vary across ecosystems, infrastructure types, and development intensities (sensu Francis et al. 2009 and Bernath-Plaisted and Koper 2016). In sagebrush ecosystems, nest survival rates of ground- and shrub-nesting birds tend to be higher in undisturbed habitats when compared to habitats that have been modified by energy development activities (Heathcoat and Chalfoun 2015a, Kirol et al. 2015b). The oil and gas development in our study area was in the production phase and had been in place for approximately 8 years at the beginning of the study. The amount of human activity and vehicle traffic is at its peak when oil and gas fields are first being developed and subsides once the wells are drilled and the infrastructure is in place (Ingelfinger and Anderson 2004, Sawyer et al. 2009). In our study, active wells were generally monitored by vehicle every 1-2 days. Gilbert and Chalfoun (2011) did not observe a decline in Brewer's Sparrow abundance in response to greater well densities. Similar to our active treatment, their study area experienced low traffic volumes of about 5 vehicles per day (Gilbert and Chalfoun 2011).

We detected a relationship between the amount of active disturbance and nest survival at a localized scale (50m radius). Because we detect a relationship at a finer spatial scale, but did not detect in difference in nest survival across treatments and the control at a broad scale, our findings suggest that impacts on nest survival are acting at a local scale. The likelihood of a Brewer's Sparrow nest being depredated increased when the footprint of active disturbance increased beyond a certain level $(\sim 15 \%$ active disturbance). Nest survival did not appear to be influenced by exposure to active disturbance below $15 \%$; however, once active disturbance surpassed this level, nest predation risk began to increase and increased more dramatically when disturbance exceeded $30 \%$ of the surrounding habitat patch. This finding suggests there is a level of active disturbance beyond which nest predators are either more abundant or more efficient at discovering nests. Although at a much larger scale $\left(1-\mathrm{km}^{2}\right.$ area), nest predation risk in sagebrush breeding songbirds increases as the footprint of energy disturbance increases (Heathcoat and Chalfoun 2015a). Heathcoat and Chalfoun (2015a) demonstrated that with every percent ( $1 \mathrm{ha}$ ) disturbance within a $1-\mathrm{km}^{2}$ area the probability of Brewer's Sparrow nest survival decreased by $1.3 \%$ 
and the probability of Sage Thrasher nest survival decreased by $3.2 \%$. Using video monitoring at nest sites and predator surveys, they attribute the elevated nest predation rates to an increased abundance and a different assemblage of nest predators associated with increasing energy disturbances (Heathcoat and Chalfoun 2015b).

The majority of Brewer's Sparrows in the active treatment area $(\sim 80 \%)$ nested in sagebrush patches that were exposed to $\leq 15 \%$ disturbance and the average distance from active disturbance edge was $60 \mathrm{~m}$. Assuming an average Brewer's Sparrow territory size of 0.25 hectares and assuming that nests were generally positioned more centrally within territories, rather than at the edge of the territories (Rotenberry et al. 1999, Harrison et al. 2009), 66\% of the nests in the active treatment had no anthropogenic disturbance within their territories. That is, $66 \%$ of nests were at least $30 \mathrm{~m}$ from active edge. This nest distribution pattern suggests some avoidance of active disturbance by Brewer's Sparrow when choosing nest sites. The pattern we observed of nest placement farther from active disturbance likely contributed to the lack of strong support for the relationship we detected between the amount of active disturbance and nest survival. This is reflected in the widening confidence intervals in Fig. 4 as disturbance levels increase and the data becomes thinner (i.e., there fewer nests to inform the survival model at these higher active disturbance levels). Other species of shrub and grassland birds also avoid anthropogenic development features at scales similar to the territory size of each species (Bayne and Dale 2011, Ludlow et al. 2015, Thompson et al. 2015). Ludlow et al. (2015) found that Baird's Sparrows (Ammodramus bairdii), a grassland specialist, selected nest sites at least $100 \mathrm{~m}$ from well access roads which corresponds to their territory size. Therefore, most often Baird's Sparrows were selecting nesting territories that did not overlap roads or road edges.

Birds will alter their nest site choices in response to predator pressure across scales (Peluc et al. 2008, Lima 2009). Recognition by Brewer's Sparrows of increased risk of nesting in areas with higher levels of active disturbance may explain why the majority of nest sites in the active development area were in sagebrush patches that had less surrounding disturbance. Harrison and Green (2010) found that previous reproductive success was highly correlated with Brewer's Sparrow territory choices. Seventy-one percent of returning Brewer's Sparrows that had successful nests the previous year returned to the same territory while only $28 \%$ of birds that were unsuccessful the previous year returned to the same territory (Harris and Green 2010).

The pattern of nest site placement relative to reclamation was very similar to the active treatment area. Nest sites in the reclamation treatment were primarily in less disturbed areas with only $17 \%$ of nests in sagebrush patches with higher levels of disturbance $(15-45 \%$ disturbance) within $50 \mathrm{~m}$ and $78 \%$ of nest territories (i.e., 0.25 hectares or $30 \mathrm{~m}$ radius) did not contain any reclaimed surfaces. The consistency in the nest distribution suggests that when choosing territories Brewer's Sparrow are responding similarly to active and reclamation surfaces. No other research has examined sagebrush songbird responses to reclamation; however, Carlisle et al. (2018) found that Brewer's Sparrows nested approximately $35 \mathrm{~m}$ from mowed sagebrush edges. The mowing treatments created edges and surfaces similar to our reclamation sites in that the majority of mature sagebrush in mowed areas was removed but grasses and forb ground cover remained (Carlisle et al. 2018). Similar to our reclamation treatment, the mowing disturbance fragments sagebrush stands and increases edge but was not associated with devegetated surfaces, persistent human activity, and infrastructure as in our active oil and gas areas.

The pattern we observed of nest placement primarily within the interior of sagebrush patches within both the reclamation and active treatments may partly explain why we did not detect a difference in nest survival broadly between reclamation and active treatments and the control. Combined our findings suggest that nests within the interior of sagebrush patches, surrounded by more sagebrush cover, are at lower risk of predation. The majority of nests sites in both the reclamation and active treatment areas were within the interior of sagebrush patches and, based on our findings, these nests likely experiencing similar predation risk. Therefore, possible survival differences across the treatments and control may not have manifested because of the preference of Brewer's Sparrows for placing nests within the interior of sagebrush patches and away from disturbance.

Despite the similarities in the spatial distribution of nests throughout both active and reclamation areas, our findings provide some evidence that nest predation risk differed. Nesting in sagebrush patches with $>15 \%$ disturbance appeared to be maladaptive in active areas but inconsequential to nest survival in reclamation areas. That is, when we applied our active disturbance survival model to reclamation there was no relationship between Brewer's Sparrow nest survival and the footprint of reclamation. This finding provides evidence that, at a local-scale, removal of oil and gas infrastructure and the associated activity had a positive influence on Brewer's Sparrow nest survival in the reclaimed treatment area. Similarly, Carlisle et al. (2018) found that vicinity to a mowed treatment was not negatively correlated with Brewer's Sparrow nest survival and nests closer to mowed edges actually had marginally higher survival rates.

Indicator species are used to "indicate" condition or a response to environmental stressors that may apply to other species with similar ecological requirements (Neimi and McDonald 2004). The relationships we detected between Brewer's Sparrows nest survival and oil and gas development and reclamation, as well as sagebrush cover, are likely indicative of other songbird species breeding in these same sagebrush habitats. At the broader spatial scales, these species are exposed to similar environmental conditions and similar nest predation pressures as Brewer's Sparrows (Vander Haegen et al. 2002, Heathcoat and Chalfoun 2015b). Other songbird nests that we recorded in our nestsearching plots included Lark Bunting $(n=17)$, Lark Sparrow $(n=22)$, and Vesper Sparrow $(n=12)$. These species all built opencup nests on the ground under the shelter of sagebrush shrubs (Barlow et al. 2019, Fedy and Kirol unpublished data). In sagebrush habitats in Washington and Wyoming, lower nest survival in habitats fragmented by human activities was consistent across a suite of ground- and shrub-nesting songbirds (e.g., Brewer's Sparrows, Sagebrush Sparrows [Artemisiopiza nevadensis], Sage Thrashers). The increased nest predation in these fragmented habitats was attributed to rodent nest predators 
achieving greater abundance in these areas (Vander Haegen et al. 2002, Hethcoat and Chaloun 2015b, Sanders and Chalfoun 2019). Therefore, we suggest that because Brewer's Sparrow nests are experiencing greater predation risk in sagebrush patches with less sagebrush cover and higher levels of active disturbance, it is probable that these co-occurring songbird species were also experiencing greater nest predation risk.

Based on this study, we suggest that oil and gas reclamation, in the short-term, does act to improve nest survival of the Brewer's Sparrow locally. However, the importance of sagebrush to Brewer's Sparrow nest survival suggests that impacts on nest survival will continue until sagebrush is restored to its predisturbance size and structure on reclamation surfaces. If the goal of oil and gas reclamation is achieving similar habitat quality as the pre-disturbance habitat for sagebrush-obligate songbirds, active restoration, such as sagebrush planting, may be necessary to ensure the reestablishment of sagebrush in reclamation areas (Pyke et al. 2015).

Our research is the first to explore a fitness response to oil and gas reclamation in a sagebrush breeding songbird. At a local scale, we found different nest survival responses in the active and reclamation treatment areas, providing some evidence that infrastructure associated with active disturbance may be more influential on Brewer's Sparrow nest predation risk than the actual footprint of disturbance. Consequently, short-term reclamation seemed to provide an immediate benefit to Brewer' Sparrow nest survival when infrastructure is removed. Yet, because sagebrush canopy cover and composition is important to Brewer's Sparrow nest survival at the nest site and surrounding areas, reclamation will not fully mitigate oil and gas development impacts on nest survival until sagebrush is reestablished on reclamation surfaces. Brewer's Sparrows showed a similar pattern of avoidance of both reclamation edge and active edge when establishing nest sites and, given the absence of sagebrush directly within the disturbance scars, it is unsurprising that we did not find a single Brewer's Sparrow nest within the reclamation footprint $\leq 5$ years after reclamation took place. It is important to emphasize that we identified a fitness response to reclamation in the short term but the legacy of oil and gas disturbances (i.e., disturbance scars) in sagebrush areas will remain for decades. That is, successful reclamation of sagebrush landcover is a long-term process (Baker 2011, Avirmed et al. 2015). Therefore, studies on decades old reclamation areas are needed to provide a more complete understanding of bird responses to reclamation.

Responses to this article can be read online at: https://www.ace-eco.org/issues/responses.php/1913

\section{Acknowledgments:}

We thank W. A. Ostheimer, J. J. Gonzales, R. T. Fieldgrove, C. C. Keefe, D. J. Thiele, D. Long, and the Northeast Sage-Grouse Local Working Group for continued support on this project. We thank N. Barlow for valuable input and assistance on many components of this research. Thank you to J. Carlisle for help with field sampling design and development. We thank H. V. Watkins, T. B. Giesler, T. C. Mort, T. S. Thorvaldson, S. M. Jenniskens, J. S. Lange, J. A.
Galloway, M. J. Alexander, L. McAndrew, N. Joakim, and all Bureau of Land Management interns for assistance during the field seasons. We thank all of the landowners who allowed us access to their properties. Funding was provided by the Northeast SageGrouse Local Working Group, the Bureau of Land Management, the Canadian Foundation for Innovation, and the Natural Sciences and Engineering Research Council of Canada (reference number 5053-10694).

\section{LITERATURE CITED}

Allred, B. W., K. W. Smith, D. Twidwell, J. H. Haggerty, S. W. Running, D. E. Naugle, and S. D. Fuhlendorf. 2015. Ecosystem services lost to oil and gas in North America: net primary production reduced in crop and rangelands. Science 348:401-402. https://doi.org/10.1126/science.aaa4785

Andersen, M. A., R. H. Coupal, and B. White. 2009. Reclamation costs and regulation of oil and gas development with application to Wyoming. Western Economics Forum 8:40-48

Andrén, H. 1994. Effects of habitat fragmentation on birds and mammals in landscapes with different proportions of suitable habitat: a review. Oikos 71:355-366. https://doi.org/10.2307/3545823

Arnold, T. W. 2010. Uninformative parameters and model selection using Akaike's information criterion. Journal of Wildlife Management 74:1175-1178. https://doi.org/10.1111/j.1937-2817.2010. tb01236.x

Avirmed, O., W. K. Lauenroth, I. C. Burke, and M. L. Mobley. 2015. Sagebrush steppe recovery on 30-90-year-old abandoned oil and gas wells. Ecosphere 6:art115. https://doi.org/10.1890/ es14-00175.1

Baker, M. F., R. L. Eng, J. S. Gashwiler, M. H. Schroeder, and C. E. Braun. 1976. Conservation committee report on effects of alteration of sagebrush communities on the associated avifauna. The Wilson Bulletin 88:165-171.

Baker, W. L. 2011. Pre-euro-american and recent fire in sagebrush ecosystems. Studies in Avian Biology 38:185-201.

Barlow, N. L., C. P. Kirol, K. E. Doherty, and B. C. Fedy. 2019. Evaluation of the umbrella species concept at fine spatial scales. The Journal of Wildlife Management 84:237-248. https://doi. org/10.1002/jwmg.21791

Barlow, N. L., C. P. Kirol, and B. C. Fedy. 2020. Avian community response to landscape-scale habitat reclamation. Biological Conservation 252:108850. https://doi.org/10.1016/j.biocon.2020.108850

Bayne, E. M. and B. C. Dale. 2011. Effects of energy development on songbirds. Pages 95-114 in D. E. Naugle, editor. Energy development and wildlife conservation in western North America. Island Press, Washington D.C. USA. https://doi. org/10.5822/978-1-61091-022-4_6

Bernath-Plaisted, J., and N. Koper. 2016. Physical footprint of oil and gas infrastructure, not anthropogenic noise, reduces nesting success of some grassland songbirds. Biological Conservation 204:434-441. https://doi.org/10.1016/j.biocon.2016.11.002

Bolker, B. M., M. E. Brooks, C. J. Clark, S. W. Geange, J. R. Poulsen, M. H. Stevens and J. S. White. 2009. Generalized linear 
mixed models: a practical guide for ecology and evolution. Trends in Ecology and Evolution 24:127-135. https://doi.org/10.1016/j. tree.2008.10.008

Burnham, K. P. and D. R. Anderson. 2002. Model selection and inference: a practical information-theoretic approach. Second edition. Springer-Verlag, New York, USA.

Carlisle, J. D., A. D. Chalfoun, K. T. Smith, and J. L. Beck. 2018. Nontarget effects on songbirds from habitat manipulation for Greater Sage-Grouse: Implications for the umbrella species concept. Condor 120:439-455. https://doi.org/10.1650/CONDOR-17-200.1

Chalfoun, A. D., F. R. Thompson III, and M. J. Ratnaswamy. 2002. Nest predators and fragmentation: a review and metaanalysis. Conservation Biology 16:306-318. https://doi. org/10.1046/j.1523-1739.2002.00308.x

Chalfoun, A. D., and T. E. Martin. 2007. Assessments of habitat preferences and quality depend on spatial scale and metrics of fitness. Journal of Applied Ecology 44:983-992. https://doi. org/10.1111/j.1365-2664.2007.01352.X

Clement, J. P., A. d'A Belin, M. J. Bean, T. A. Boling and J. R. Lyons. 2014. A strategy for improving the mitigation policies and practices of the Department of the Interior. A report to the Secretary of the Interior from the Energy and Climate Change Task Force. Washington, D.C. USA.

Coates, P. S., and D. J. Delehanty. 2010. Nest predation of greater sage-grouse in relation to microhabitat factors and predators. Journal of Wildlife Management 74:240-248. https://doi. org/10.2193/2009-047

Copeland, H. E., A. Pocewicz, and J. M. Kiesecker. 2011. Geography of energy development in western North America: potential impacts on terrestrial ecosystems. Pages 7-22 in D. E. Naugle, editor. Energy development and wildlife conservation in western North America. Island Press, Washington, D.C., USA. https://doi.org/10.5822/978-1-61091-022-4_2

Davies K. W., C. S. Boyd, J. L. Beck, J. D. Bates, T. J. Svejcar, and M. A. Gregg. 2011. Saving the sagebrush sea: an ecosystem conservation plan for big sagebrush plant communities. Biological Conservation 144:2573-2584 https://doi.org/10.1016/j. biocon.2011.07.016

Davies, K. W., C. S. Boyd, and A. M. Nafus. 2013. Restoring the sagebrush component in crested wheatgrass-dominated communities. Rangeland Ecology and Management 66:472-478. https://doi.org/10.2111/REM-D-12-00145.1

DeGregorio, B. A., P. J. Weatherhead, and J. H. Sperry. 2014. Power lines, roads, and avian nest survival: Effects on predator identity and predation intensity. Ecology and Evolution 4:1589-1600. https://doi.org/10.1002/ece3.1049

Dinsmore, S. J., G. C. White, and F. L. Knopf. 2002. Advanced techniques for modeling avian nest survival. Ecology 83:3476-3488. https://doi.org/10.1890/0012-9658(2002)083[3476: ATFMAN]2.0.CO;2

Doherty, K. E., D. E. Naugle, and B. L. Walker. 2010. Greater Sage-Grouse nesting habitat: the importance of managing at multiple scales. Journal of Wildlife Management 74:1544-1553. https://doi.org/10.1111/j.1937-2817.2010.tb01282.x

Ehrlich, P. R., D. S. Dobkin, and D. Wheye. 1988. The birder's hand-book: a field guide to the natural history of North American birds. Simon \& Schuster, New York, USA.

Evans, J. S., J. Oakleaf, S. A. Cushman, and D. Theobald. 2014. An ArcGIS Toolbox for Surface Gradient and Geomorphometric Modeling, version 2.0-0. [online] URL: https://evansmurphy. wixsite.com/evansspatial/arcgis-gradient-metrics-toolbox

Fedy, B. C. and Martin, K. 2011. The influence of fine-scale habitat features on regional variation in population performance of alpine white-tailed ptarmigan. Condor 113:306-315. https:// doi.org/10.1525/cond.2011.100070

Fedy, B. C., C. P. Kirol, A. L. Sutphin, and T. L. Maechtle. 2015. The influence of mitigation on sage-grouse habitat selection within an energy development field. PLoS ONE 10(4): e0121603. https://doi.org/10.1371/journal.pone.0121603

Francis, C. D., C. P. Ortega, and A. Cruz. 2009. Noise pollution changes avian communities and species interactions. Current Biology 19:1415-1419. https://doi.org/10.1016/j.cub.2009.06.052

Gasch, C. K., S. V. Huzurbazar, and P. D. Stahl. 2016. Description of vegetation and soil properties in sagebrush steppe following pipeline burial, reclamation, and recovery time. Geoderma 265:19-26. https://doi.org/10.1016/j.geoderma.2015.11.013

Gilbert, M. M., and A. D. Chalfoun. 2011. Energy development affects populations of sagebrush songbirds in Wyoming. Journal of Wildlife Management 75:816-824. https://doi.org/10.1002/ jwmg. 123

Hall, L. S., P. R. Krausman, and M. L. Morrison. 1997. The habitat concept and a plea for standard terminology. Wildlife Society Bulletin 25:173-182.

Hanser, S. E., M. Leu, C. L. Aldridge, S. E. Nielsen, and S. T. Knick. 2011. Occurrence of small mammals: Deer mice and the challenge of trapping across large spatial extents. Pages 337-356 in S. E. Hanser, M. Leu, S. T. Knick, and C. L. Aldridge, editors. Sagebrush ecosystem conservation and management: ecoregional assessment tools and models for the Wyoming Basins. Allen Press, Lawrence, Kansas, USA.

Hansley, P. L., and G. P. Beauvais. 2004. Species assessment for Brewer's Sparrow (Spizella breweri) in Wyoming. Department of the Interior, Bureau of Land Management, Wyoming State Office, Cheyenne, Wyoming, USA.

Harrison, M. L., D. J. Green, and P. G. Krannitz. 2009. Conspecifics influence the settlement decisions of male Brewer's Sparrows at the northern edge of their range. Condor 111:722-729. https://doi.org/10.1525/cond.2009.090126

Harrison, M. L., and D. J. Green. 2010. Vegetation influences patch occupancy but not settlement and dispersal decisions in a declining migratory songbird. Canadian Journal of Zoology 88:148-160. https://doi.org/10.1139/Z09-125

Hethcoat, M. G., and A. D. Chalfoun. 2015a. Energy development and avian nest survival in Wyoming, USA: A test of 
a common disturbance index. Biological Conservation 184:327-334. https://doi.org/10.1016/j.biocon.2015.02.009

Hethcoat, M. G., and A. D. Chalfoun. 2015b. Towards a mechanistic understanding of human-induced rapid environmental change: A case study linking energy development, nest predation and predators. Journal of Applied Ecology 52:1492-1499. https:// doi.org/10.1111/1365-2664.12513

Homer, C. G., C. L. Aldridge, D. K. Meyer, and S. J. Schell. 2012. Multi-scale remote sensing sagebrush characterization with regression trees over Wyoming, USA: Laying a foundation for monitoring. International Journal of Applied Earth Observation and Geoinformation 14:233-244. https://doi.org/10.1016/j. jag.2011.09.012

Hosmer, D. W., and S. Lemeshow. 2008. Applied survival analysis: regression modeling of time to event data. Second edition. John Wiley and Sons, New York, USA. https://doi.org/10.1002/9780470258019

Howe, K. B., P. S. Coates, and D. J. Delehanty. 2014. Selection of anthropogenic features and vegetation characteristics by nesting Common Ravens in the sagebrush ecosystem. Condor 116:35-49. https://doi.org/10.1650/CONDOR-13-115-R2.1

Ibáñez-Álamo, J. D., R. D. Magrath, J. C. Oteyza, A. D. Chalfoun, T. M. Haff, K. A. Schmidt, R. L. Thomson, and T. E. Martin. 2015. Nest predation research: recent findings and future perspectives. Journal of Ornithology 156:247-262. https://doi. org/10.1007/s10336-015-1207-4

Ingelfinger, F., and S. Anderson. 2004. Passerine response to roads associated with natural gas extraction in a sagebrush steppe habitat. Western North American Naturalist 64:385-395.

Jones, M. O., B. W. Allred, D. E. Naugle, J. D. Maestas, P. Donnelly, L. J. Metz, J. Karl, R. Smith, B. Bestelmeyer, C. Boyd, J. D. Kerby, and J. D. McIver. 2018. Innovation in rangeland monitoring: annual, $30 \mathrm{~m}$, plant functional type percent cover maps for U.S. rangelands, 1984-2017. Ecosphere 9:e02430. https:// doi.org/10.1002/ecs2.2430

Jongsomjit, D., S. L. Jones, T. Gardali, G. R. Geupel, and P. J. Gouse. 2007. A guide to nestling development and aging in altricial passerines. Biological Technical Publication BTPR6008-2007. U.S. Department of Interior, Fish and Wildlife Service, Washington, D.C., USA.

Kéry, M, and J. A. Royle. 2016. Applied hierarchical modeling in ecology: analysis of distribution, abundance and species richness in R and BUGS. Vol. 1, prelude and static models. Academic Press, London, UK.

Knick, S. T., D. S. Dobkin, J. T. Rotenberry, M. A. Schroeder, W. M. Vander Haegen, and C. van Riper. 2003. Teetering on the edge or too late? Conservation and Research Issues for Avifauna of Sagebrush Habitats. Condor 105:611-634. https://doi.org/10.1093/ condor/105.4.611

Kirol, C. P., J. L. Beck, S. V. Huzurbazar, M. J. Holloran, and S. N. Miller. 2015a. Identifying greater sage-grouse source and sink habitats for conservation planning in an energy development landscape. Ecological Applications 25:968-990. https://doi. org/10.1890/13-1152.1
Kirol C. P., A. L. Sutphin, L. Bond, M. R. Fuller and T. M. Maechtle. 2015b. Mitigation effectiveness for improving nesting success of greater sage-grouse influenced by energy development. Wildlife Biology 21:98-109. https://doi.org/10.2981/wlb.00002

Kirol, C. P., K. L. Pilgrim, A. L. Sutphin, and T. L. Maechtle. 2018. Using DNA from hairs left at depredated greater sagegrouse nests to detect mammalian nest predators. Wildlife Society Bulletin 42:160-165. https://doi.org/10.1002/wsb.853

Kirol, C. P., K. T. Smith, N. E. Graf, J. B. Dinkins, C. W. Lebeau, T. L. Maechtle, A. L. Sutphin, and J. L. Beck. 2020. Greater sagegrouse response to the physical footprint of energy development. Journal of Wildlife Management 84:989-1001. https://doi. org/10.1002/jwmg.21854

Lima, S. L. 2009. Predators and the breeding bird: behavioral and reproductive flexibility under the risk of predation. Biological Reviews 84:485-513. https://doi.org/10.1111/j.1469-185X.2009.00085. $\mathrm{x}$

Liebezeit, J. R., S. J. Kendall, S. Brown, C. B. Johnson, P. Martin, T. L. McDonald, D. C. Payer, C. L. Rea, B. Streever, A. M. Wildman, and S. Zack. 2009. Influence of human development and predators on nest survival of tundra birds, Arctic Coastal Plain, Alaska. Ecological Applications 19:1628-1644. https://doi. org/10.1890/08-1661.1

Latif, Q. S., S. K. Heath, and J. T. Rotenberry. 2012. How avian nest site selection responds to predation risk: testing an "adaptive peak hypothesis.” Journal of Animal Ecology 81:127-138. https:// doi.org/10.1111/j.1365-2656.2011.01895.x

Lloyd, P., T. E. Martin, U. Langner, and M. M. Hart. 2005. Linking demographic effects of habitat fragmentation across landscapes to continental source-sink dynamics. Ecological Applications 15:1504-1514. https://doi.org/10.1890/04-1243

Ludlow, S. M., R. M. Brigham, and S. K. Davis. 2015. Oil and natural gas development has mixed effects on the density and reproductive success of grassland songbirds. Condor 117:64-75. https://doi.org/10.1650/CONDOR-14-79.1

Mahony, N. A., W. M. Vander Haegen, B. L. Walker, and P. G. Krannitz. 2001. Male incubation and multiple brooding in sagebrush Brewer's Sparrows. The Wilson Bulletin 113:441-444. https://doi.org/10.1676/0043-5643(2001)113[0441:MIAMBI]2.0.CO;2

Maresh Nelson, S. B., J. J. Coon, C. J. Duchardt, J. R. Miller, D. M. Debinski, and W. H. Schacht. 2018. Contrasting impacts of invasive plants and human-altered landscape context on nest survival and brood parasitism of a grassland bird. Landscape Ecology 33:1799-1813. https://doi.org/10.1007/s10980-018-0703-3

Martin, T. E. 1993. Nest predation and nest sites. BioScience 43:523-532. https://doi.org/10.2307/1311947

Martin, T. E., and G. R. Geupel. 1993. Nest-monitoring plots: methods for locating nests and monitoring success. Journal of Field Ornithology 64:507-519.

Murcia, C. 1995. Edge effects in fragmented forests: implications for conservation. Trends in Ecology and Evolution 10:58-62. https://doi.org/10.1016/S0169-5347(00)88977-6 
Niemi, G. J., and M. E. McDonald. 2004. Application of ecological indicators. Annual Review of Ecology, Evolution, and Systematics 35:89-111. https://doi.org/10.1146/annurev. ecolsys.35.112202.130132

Nur, N., A. L. Holmes, and G. R. Geupel. 2004. Use of survival time analysis to analyze nesting success in birds: an example using loggerhead shrikes. Condor 106:457-471 https://doi.org/10.1093/ condor/106.3.457

Peluc, S. I., T. S. Sillett, J. T. Rotenberry, and C. K. Ghalambor. 2008. Adaptive phenotypic plasticity in an island songbird exposed to a novel predation risk. Behavioral Ecology 19:830-835. https://doi.org/10.1093/beheco/arn033

Petersen, K. L., L. B. Best, and B. M. Winter. 1986. Growth of nestling Sage Sparrows and Brewer's Sparrows. The Wilson Bulletin 98:535-546.

Pyke, D. A., J. C. Chambers, M. Pellant, S. T. Knick, R. F. Miller, J. L. Beck, P. S. Doescher, E. W. Schupp, B. A. Roundy, M. Brunson, and J. D. McIver. 2015. Restoration handbook for sagebrush steppe ecosystems with emphasis on greater sagegrouse habitat-Part 1. Concepts for understanding and applying restoration: U.S. Geological Survey Circular 1416:1-44. https:// doi.org/10.3133/cir1416

Robinson, S. K., F. R. Thompson III, T. M. Donovan, D. R. Whitehead, and J. Faaborg. 1995. Regional forest fragmentation and the nesting success of migratory birds. Science 267:1987-1990 https://doi.org/10.1126/science.267.5206.1987

Robertson, B. A., and R. L. Hutto. 2006. A framework for understanding ecological traps and an evaluation of existing evidence. Ecology 87:1075-1085. https://doi.org/10.1890/0012-9658 (2006)87[1075:AFFUET]2.0.CO;2

Robinson, N. P., B. W. Allred, M. O. Jones, A. Moreno, J. S. Kimball, D. E. Naugle, T. A. Erickson, and A. D. Richardson. 2017. A dynamic landsat derived normalized difference vegetation index (NDVI) product for the conterminous United States. Remote Sensing 9:1-14. https://doi.org/10.3390/rs9080863

Rosenberg, K. V., J. A. Kennedy, R. Dettmers, R. P. Ford, D. Reynolds, J. D. Alexander, C. J. Beardmore, P. J. Blancher, R. E. Bogart, G. S. Butcher, A. F. Camfield, et al. 2016. Partners in Flight Landbird Conservation Plan: 2016 Revision for Canada and Continental United States. Partners in Flight Science Committee.

Rotenberry, J. T., M. A. Patten, and K. L. Preston. 1999. Brewer's Sparrow (Spizella breweri). Account 390 in A. F. Poole and F. B. Gill, editors. The birds of North America. Cornell Lab of Ornithology, Ithaca, New York, USA. https://doi.org/10.2173/ bna. 390

Rottler, C. M., I. C. Burke, K. A. Palmquist, J. B. Bradford, and W. K. Lauenroth. 2018. Current reclamation practices after oil and gas development do not speed up succession or plant community recovery in big sagebrush ecosystems in Wyoming. Restoration Ecology 26:114-123. https://doi.org/10.1111/rec.12543

Rowland, M. M., M. J. Wisdom, L. H. Suring, and C. W. Meinke. 2006. Greater sage-grouse as an umbrella species for sagebrush- associated vertebrates. Biological Conservation 129:323-335. https://doi.org/10.1016/j.biocon.2005.10.048

Ruehmann, M. B., M. J. Desmond, and W. R. Gould. 2011. Effects of smooth brome on Brewer's Sparrow nest survival in sagebrush steppe. Condor 113:419-428. https://doi.org/10.1525/cond.2011.100022

Saether, B. E., and O. Bakke. 2000. Avian life history variation and contribution of demographic traits to the population growth rate. Ecology 81:642-653. https://doi.org/10.2307/177366

Sanders, L. E., and A. D. Chalfoun. 2018. Novel landscape elements within natural gas fields increase densities but not fitness of an important songbird nest predator. Biological Conservation 228:132-141. https://doi.org/10.1016/j.biocon.2018.10.020

Sanders, L. E., and A. D. Chalfoun. 2019. Mechanisms underlying increased nest predation in natural gas fields: a test of the mesopredator release hypothesis. Ecosphere 10:e02738. https:// doi.org/10.1002/ecs2.2738

Sauer, J. R., W. A. Link, J. E. Fallon, K. L. Pardieck, and D. J. Ziolkowski, Jr. 2013. The North American Breeding Bird Survey 1966-2011: Summary Analysis and Species Accounts. North American Fauna 79:1-32. https://doi.org/10.3996/nafa.79.0001

Sawyer, H., M. J. Kauffman, and R. M. Nielson. 2009. Influence of well pad activity on winter habitat selection patterns of mule deer. Journal of Wildlife Management 73:1052-1061. https://doi. org/10.2193/2008-478

Shaffer, T. L. 2004. A unified approach to analyzing nest success. The Auk 121:526-540. https://doi.org/10.1642/0004-8038(2004) 121[0526:AUATAN]2.0.CO;2

Stephens, S. E., D. N. Koons, J. J. Rotella, and D. W. Willey. 2004 Effects of habitat fragmentation on avian nesting success: A review of the evidence at multiple spatial scales. Biological Conservation 115:101-110. https://doi.org/10.1016/S0006-3207 (03)00098-3

Therneau, T. 2019. Package 'survival'. R package version 3.1-8. [online] URL: https://cran.r-project.org/web/packages/survival/ index.html

Therneau, T. 2020. coxme: Mixed Effects Cox Models. R package version 2.2-16. [online] URL: https://cran.r-project.org/web/ packages/coxme/index.html

Thompson, S. J., D. H. Johnson, N. D. Niemuth, and C. A. Ribic. 2015. Avoidance of unconventional oil wells and roads exacerbates habitat loss for grassland birds in the North American great plains. Biological Conservation 192:82-90. https://doi. org/10.1016/j.biocon.2015.08.040

U.S. Bureau of Land Management. 2003. Record of decision and resource management plan amendments for the Powder River Basin oil and gas project. WY-070-02-065. Bureau of Land Management-Wyoming State Office, USA.

U.S. Fish and Wildlife Service. 2013. Greater Sage-grouse (Centrocercus urophasianus) conservation objectives: Final report. U.S. Fish and Wildlife Service, Denver, Colorado, USA.

Vander Haegen, W. M., M. A. Schroeder, and R. M. DeGraaf. 2002. Predation on real and artificial nests in shrubsteppe 
landscapes fragmented by agriculture. Condor 104:496-506. https://doi.org/10.1093/condor/104.3.496

Vander Haegen, W. M. 2007. Fragmentation by agriculture influences reproductive success of birds in a shrubsteppe landscape. Ecological Applications 17:934-947. https://doi. org/10.1890/06-0990

Van Rensen, C. K., S. E. Nielsen, B. White, T. Vinge, and V. J. Lieffers. 2015. Natural regeneration of forest vegetation on legacy seismic lines in boreal habitats in Alberta's oil sands region. Biological Conservation 184:127-135. https://doi.org/10.1016/j. biocon.2015.01.020

Walker, B. L., M. A. Neubaum, S. R. Goforth, and M. M. Flenner. 2020. Quantifying habitat loss and modification from recent expansion of energy infrastructure in an isolated, peripheral greater sage-grouse population. Journal of Environmental Management 255:109819. https://doi.org/10.1016/j.jenvman.2019.109819

Walker, B. L. 2004. Effects of management practices on grassland birds: Brewer's Sparrow. Northern Prairie Wildlife Research Center, Jamestown, North Dakota, USA. https://doi. org/10.3133/70159775

Webb, S. L., C. V. Olson, M. R. Dzialak, S. M. Harju, J. B. Winstead, and D. Lockman. 2012. Landscape features and weather influence nest survival of a ground-nesting bird of conservation concern, the greater sage-grouse, in human-altered environments. Ecological Processes 1:1-15. https://doi.

org/10.1186/2192-1709-1-4

Williams, M. I., G. B. Paige, T. L. Thurow, A. L. Hild, and K. G. Gerow. 2011. Songbird relationships to shrub-steppe ecological site characteristics. Rangeland Ecology \& Management 64:109-118. https://doi.org/10.2111/rem-d-10-00076.1

Winter, M., N. H. Johnson, J. Faaborg. 2000. Evidence of edge effects on multiple levels in tallgrass prairie. Condor 102: 256-266. https://doi.org/10.1093/condor/102.2.256

Xian, G., C. Homer, M. Rigge, H. Shi, and D. Meyer. 2015. Characterization of shrubland ecosystem components as continuous fields in the northwest United States. Remote Sensing of Environment 168:286-300. https://doi.org/10.1016/j.rse.2015.07.014

Yang, L., S. Jin, P. Danielson, C. Homer, L. Gass, S. M. Bender, A. Case, C. Costello, J. Dewitz, J. Fry, M. Funk, B. Granneman, G. C. Liknes, M. Rigge, and G. Xian. 2018. A new generation of the United States National Land Cover Database: Requirements, research priorities, design, and implementation strategies. ISPRS Journal of Photogrammetry and Remote Sensing 146:108-123. https://doi.org/10.1016/j.isprsjprs.2018.09.006

Yoo, J. G. 2014. Effects of natural gas well development on songbird reproductive success in mixed-grass prairies of southeastern Alberta. Thesis. University of Manitoba, Winnipeg, Canada.

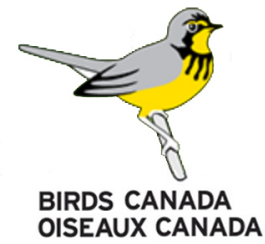


Appendix 1 - Example of reclaimed coal-bed natural gas (CBNG) infrastructure features, northeastern Wyoming, USA.

\section{Fig. A1.1}

A reclaimed CBNG access road taken in 2016 in northestern Wyoming, USA.

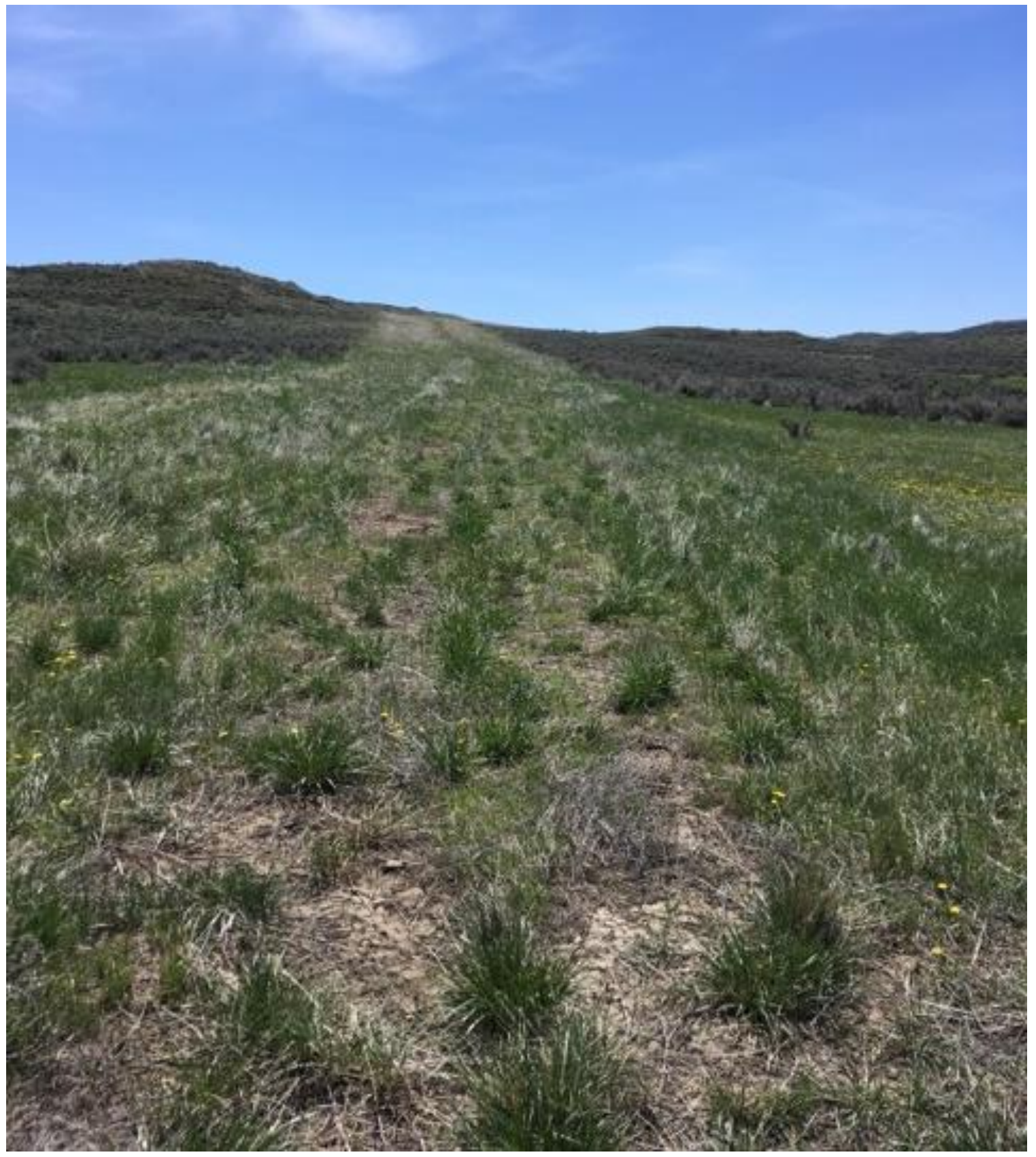


Fig. A1.2

A reclaimed CBNG well pad taken in 2017 in northestern Wyoming, USA.

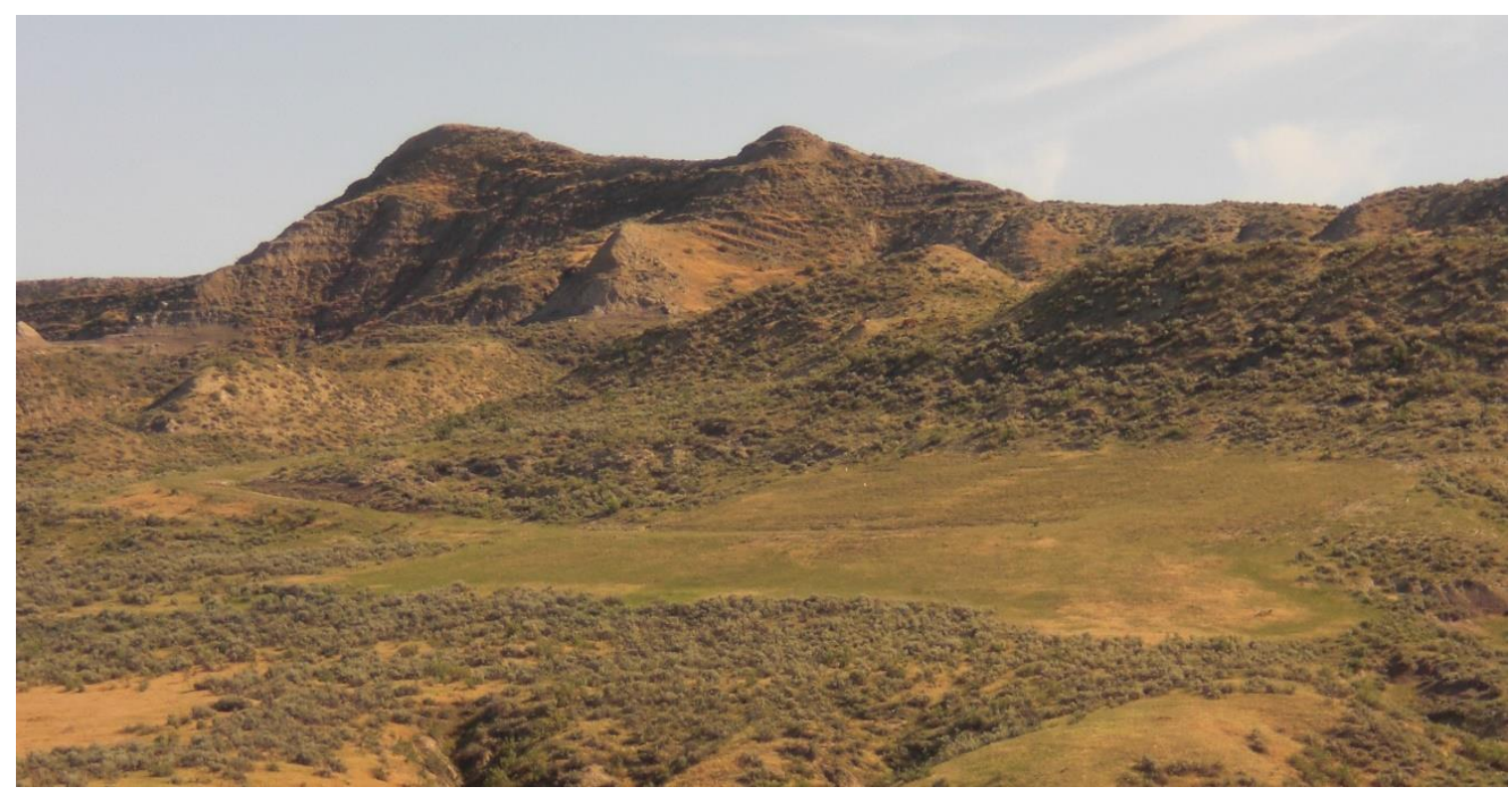

